\title{
PENERAPAN EUCLIDEAN PROBABILITY DALAM PENDETEKSIAN PENYAKIT IMPETIGO
}

\author{
Puji Sari Ramadhan \\ STMIK TRIGUNA DHARMA \\ Jl. AH Nasution No.73F, 20142, Indonesia \\ pujisariramadhan@gmail.com
}

\begin{abstract}
Abstrak-Penelitian ini membahas tentang penerapan sebuah teknologi sistem cerdas yang mampu memberikan pengetahuan tentang pendeteksian Impetigo berdasarkan gejela-gejala yang pada umumnya dialami oleh seorang pasien melalui akuisisi keilmuan pakar. Sistem yang nantinya akan dibangun bertujuan untuk meningkatkan pengetahuan masyarakat tentang penyakit Impetigo beserta gejala-gejalanya dan diharapkan mampu memberikan kemanfaatan bagi masyarakat berupa pengembangan teknologi Sistem Pakar yang nantinya dapat dijadikan layanan konsultasi publik untuk dapat diakses siapapun dan kapanpun dalam mendeteksi Impetigo secara dini sehingga dapat digunakan sebagai pengambilan kesimpulan diagnosa awal sebelum melakukan pemeriksaan intensif laboratorium. Dalam membangun layanan diagnosa ini dibutuhkan penerapan metode Euclidean Probability yang berguna untuk melakukan penelusuran serta perhitungan bobot probabilitas terhadap gejala-gejala yang terjadi sehingga nantinya akan menghasilkan nilai kemungkinan seseorang mendeita penyakit Impetigo.
\end{abstract}

Keywords - Sistem Pakar, Euclidean Probability, Impetigo.

Abstract-This paper discusses the application of an intelligent system technology that is able to provide knowledge about the detection of Impetigo based on symptoms that are generally experienced by a patient through the acquisition of expert science. The system which will be built aims to increase public knowledge about Impetigo disease and its symptoms and is expected to be able to provide benefits to the community in the form of Expert System technology development which can later be used as public consultation services for anyone and anytime to detect Impetigo early so that it can be used as the conclusion of the initial diagnosis before conducting an intensive laboratory examination. In building a diagnostic service it is necessary to apply the Euclidean Probability method which is useful for conducting searches and calculating the probability weight for the symptoms that occur so that later it will produce the value of the possibility of someone suffering from Impetigo disease.

Keywords - Expert System, Euclidean Probability Method, Impetigo.

\section{PENDAHULUAN}

Penelitian ini membahas tentang pembangunan sebuah sistem cerdas yang mampu menganalisis pendeteksian yang berkaitan tentang Impetigo. Penyakit ini merupakan jenis penyakit yang mengakibatkan munculnya lepuhan yang mengandung pustula.

Penyakit Impetigo disebabkan infeksi kuman streptokokus yang dapat muncul pada area tubuh manapun terutama pada bagian tubuh yang tingkat kebersihannya masih kurang. Penyakit ini pada umumnya menyerang seseorang yang kurang memperhatikan kebersihan tubuh serta memiliki sensifitas tinggi terhadap kondisi lingkungan, dengan didasari hal tersebut maka penyakit Impetigo ini sering kali menyerang anak ataupun balita yang diketahui sangat mudah terserang penyakit dan belum mengetahui keadaan lingkungan sekitar.

Impetigo dapat mengkibatkan terganggunya kesehatan pada kulit sampai resiko infeksi kulit kronis, namun pada saat ini sulitnya melakukan pendeteksian secara dini terhadap penyakit Impetigo mengakibatkan terhambatnya penanganan terhadap anak yang terserang penyakit tersebut, hal ini dikarenakan keterbatasan ahli mapun pakar kulit anak yang berada di daerah-daerah dan keterbatasan pengetahuan masyarakat tentang penyakit Impetigo ini.

Berdasarkan fenomena yang telah dikemukakan, maka perlu membangun sebuah sistem dengan mengembangkan konsep Arificial Intelegence yaitu Sistem Pakar.

Penggunaan Sistem Pakar didalam dunia medis sudah teruji, hal ini dpat dilihat dari jumlah penelitian tentang pendiagnosaan terhadap penyakit yang menggunakan teknologi berbasis komputer.

Sistem Pakar yang akan dirancang nantinya akan mengakuisisi informasi dan pengetahuan tentang penyakit Impetigo berdasarkan hasil dari kepakaran dan melakukan penelusuran gejala-gejala yang terjadi sehingga dapat diperoleh nilai kemungkinan seseorang menderita penyakit Impetigo.

Selain itu Sistem ini nantinya diharapkan dapat dipergunakan dalam melakukan pendeteksian terhadap 
penyakit Impetigo berdasarkan gejala-gejala klinis yang dialami oleh seseorang yang kemungkinan terjangkit Impetigo dengan menerapkan Euclidean Probability.

Dengan adanya Sistem Pakar ini nantinya diharapkan mampu memberikan kemanfaatan bagi masyarakat berupa pengembangan teknologi Sistem

Page|12 Pakar yang nantinya dapat dijadikan layanan konsultasi publik untuk dapat diakses siapapun dan kapanpun dalam mendeteksi penyakit Impetigo secara dini sehingga dapat digunakan sebagai pengambilan kesimpulan diagnosa awal sebelum melakukan pemeriksaan intensif laboratorium.

\section{LANDASAN TEORI}

Dalam melakukan penelitian ini diperlukan beberapa landasan bersifat teoritis yang berkaitan dengan Kecerdasan Buatan, Sistem Pakar, Euclidean Probability, dan Impetigo pada anak.

\section{A. Kecerdasan Buatan}

Kecerdasan buatan ialah konsep dari ilmu komputer yang mempunyai keahlian dalam menemukan solusi terhadap masalah yang ada[1]. Dalam pemaparan lainnya[2] dijelaskan pula kecerdasan buatan sebagai representasi pengetahuan yang diadopsikan ke sebuah sistem dengan pengotomatisan tingkah laku cerdas.

Pada penelitian lainnya[3] juga menjelaskan, kecerdasan buatan digambarkan sebagai mekanisme yang difokuskan pada kecerdasan dalam pembentukan konsep analisa. Dalam pemaparan lainnya[4] dijelaskan juga, kecerdasan buatan adalah sebuah mesin yang dapat melakukan dan melaksanakan pekerjaan sebaik.

\section{B. Sistem Pakar}

Sistem Pakar merupakan bagian keilmuan dari kecerdasan buatan yang memerlukan pengetahuan yang mendalam untuk memecahkan permasalahan yang kompleks[5]. Pada pendapat lainnya dalam[6] dikemukakan bahwa Sistem Pakar ialah aplikasi komputer yang berfungsi untuk menyelesaikan permasalahan.

Selain itu terdapat penelitian lainnya[7] disebutkan juga Sistem Pakar adalah jenis dari keilmuan kecerdasan buatan yang mampu melakukan analisa penyelesaian permasalahan. Dalam [8] dikemukakan Sistem Pakar adalah penghasil keputusan ketika sistem tersebut telah ada pengetahuannya. Kemudian pendapat lainnya[9] menjelaskan juga Sistem Pakar menyebabkan komputer dapat berfikir untuk mengambil keputusan berdasarkan perangkat aturan.

Selanjutnya dalam[10] dipaparkan juga Sistem Pakar merupakan aplikasi komputer yang bertujuan untuk dapat digunakan sebagai media penyedia nasehat atau sarana bantu. Kemudian dalam[11] disebutkan juga Sistem Pakar dikembangkan untuk mentransformasikan pengetahuan dan keahlian pakar ke sebuah sistem sehingga dapat meniru penalaran manusia.

Selain itu pula dalam[12] dipaparkan pula Sistem Pakar mempunyai keahlian dan kemampuan dalam menangani permasalahan ketidakpastian.

Penerapan Sistem Pakar telah banyak diimplementasikan dalam penyelesaian permasalahan diantaranya dalam[13] digunakan dalam pendeteksian Inflamasi Dermatitis Imun pada anak, selanjutnya Sistem Pakar pernah digunakan dalam [14] untuk mendeteksi kandungan formalin pada ikan bandeng. Selain itu pada penelitian lainnya[15] Sistem Pakar digunakan untuk mendeteksi penyakit Polymyalgia Rheumatic. Kemudian dalam[16] Sistem Pakar digunakan dalam pendeteksian penyakit serangga.

Dalam[17] dikemukakan pula, Sistem Pakar diimplementasikan untuk pemetaan kerentanan longsor. Selain itu Sistem Pakar pernah digunakan untuk pendiagnosaan kerusakan notebook[18]. Sistem Pakar pernah diterapkan untuk pendiagnosaan kerusakan tenaga listrik[19]. Pada penelitian [20] disebutkan juga, Sistem Pakar telah mampu melakukan diagnosa terhadap patah tulang dan dalam penelitian selanjutnya [21] dijelaskan bahwa Sistem Pakar bisa digunakan dalam pendiagnosaan Dermatitis.

\section{Euclidean Probability}

Metode ini merupakan teknik pendekatan kasus yang digunakan untuk mengukur suatu kemungkinan atau nilai kepastian dalam menghasilkan kesimpulan dan pengetahuan berdasarkan berdasarkan sebab yang terjadi. Dalam pengembangannya, teknik ini juga dapat digunakan dalam memprediksi sesuatu kejadian berdasarkan sebab atau evidence yang muncul. Berikut merupakan persamaan Euclidean Probability adalah :

$$
E P=\sqrt{\left(E_{1} * N B E_{1}\right)^{2}+\left(E_{2} * N B E_{2}\right)^{2}+\ldots+\left(E_{n} * N B E_{n}\right)^{2}}
$$

\section{Penyakit Impetigo}

Merupakan jenis infeksi kulit yang mengakibatkan munculnya lepuhan yang mengandung pustula. Penyakit Impetigo disebabkan infeksi kuman streptokokus yang dapat muncul pada area tubuh manapun terutama pada bagian tubuh yang tingkat kebersihannya masih kurang[22].

Penyakit ini memiliki manifestasi gejala-gejala, diantaranya : Bagian Tubuh Terasa Nyeri, Gatal, Kulit Melepuh, Bercak Merah, Kulit berkerak kuning, Demam, dan Pembengkakan Kelenjar.

1) Impetigo Bulos adalah jenis penyakit Impetigo yang sering menyerang pada bayi, ditandainya dengan kelainan pada kulit dan cairan yang keluar pada kulit yang mengakibatkan infeksi kulit kronis[22].

2) Impetigo Krutosa adalah jenis Impetigo yang manifestasi gejalanya dapat menular dari serangan udara, penyakit ini juga dikenal sebagai penyakit yang sering diderita oleh orang yang memiliki tingkat kebersihan yang rendah dan faktor lingkungan yang kurang baik [22]. 


\section{HASIL DAN PEMBAHASAN}

Dalam melakukan penelitian ini, pendekatan yang diterapkan adalah pendekatan kuantitatif yang berfungsi untuk menguji suatu kebenaran hipotesis berupa probabilitas penyakit Impetigo berdasarkan gejala-gejala klinis yang telah didapat dari nilai

Page | 13 kepastian atau evidence pakar yang nantinya dapat dipergunakan dalam proses analisis perhitungan Euclidean Probability, sehingga nantinya akan diketahui hasil diagnosa penyakit Impetigo yang akan diterapkan ke dalam sebuah sistem cerdas.

Selain analisis pendekatan metode, penelitian ini juga menggunakan penerapan metode penelitian berupa Reserch and Development yang mempunyai tujuan untuk dapat menghasilkan produk baru berbentuk Sistem Pakar, yang dapat dipergunakan dalam pendeteksian Impetigo dengan terlebih dahulu melakukan penelusuran dan proses perhitungan Euclidean Probability yang. Disamping itu terdapat kerangka kerja yang harus dilakukan untuk menyelesaikan penelitian ini, daftar kerangka kerja yang harus diikuti diantaranya :

\section{A. Analisa Permasalahan}

Dalam membangun sebuah sistem yang mampu mengakuisisi proses dan cara memasukkan pengetahuan dari sang pakar ke dalam komputer sehingga dapat memberikan kemudahan dalam mendiagnosa penyakit Impetigo dengan kualitas pakar.

Untuk menyelesaikan permasalahan yang terjadi maka dibutuhkan pengolahan basis pengetahuan kepakaran dari seorang pakar yang dibentuk ke dalam aturan-aturan dan fakta-fakta yang dapat menghasilkan diagnosa dan kesimpulan sesuai dengan kaidah-kaidah basis pengetahuan yang ada. Berikut ini merupakan pembentukan basis pengetahuan yang berasal dari keilmuan pakar.

TABEL I

DATA KEPAKARAN

\begin{tabular}{|c|l|c|c|}
\hline \multirow{2}{*}{$\begin{array}{c}\mathrm{N} \\
\mathrm{O}\end{array}$} & \multicolumn{2}{|c|}{ Daftar Gejala } & \multicolumn{2}{|c|}{ Impetigo } \\
\cline { 3 - 4 } & & Bulos & Krutosa \\
\hline 1 & Bagian Tubuh Terasa Nyeri & 0.6 & \\
\hline 2 & Gatal & 0.2 & \\
\hline 3 & Kulit Melepuh & 0.6 & \\
\hline 4 & Bercak Merah & 0.4 & \\
\hline 5 & Kulit berkerak kuning & 0.2 & \\
\hline 6 & Demam & & 0.6 \\
\hline 7 & Pembengkakan Kelenjar & & 0.2 \\
\hline
\end{tabular}

\section{B. Pembentukan Basis Aturan}

Setelah memperoleh knowladge base yang berkaitan dengan Impetigo dan gejala-gejala yang terjadi dan diidentifikasi, maka proses selanjutnya membentuk aturan-aturan (rule). Adapun rule base yang akan dibentuk adalah:

Rule $1:$ IF Nyeri $=$ Yes $A N D$ Gatal $=$ Yes, Kulit Melepuh $=$ Yes AND, Bercak Merah $=$ Yes $A N D$, Kulit berkerang kuning $=$ Yes THEN Penyakit $=$ Bulos

Rule 2 : IF Demam =Yes AND Pembengkakan Kelenjat $=$ Yes THEN Penyakit $=$ Krutosa .

\section{Penelurusan Forward Chaining}

Dari hasil pembentukan rule base yang ada, maka dapat dilakukan proses penelusuran gejela-gejala yang terjadi yang nantinya akan menghasilkan kesimpulan jenis penyakit yang terkena oleh anak tersebut. Berikut contoh kasus dalam proses penelusuran dengan menggunakan Forward Chaining.

Pada Kasus terbaru terdapat fakta seorang anak menderita gejala-gejala sebagai berikut :

TABEL III

DATA KASUS

\begin{tabular}{|c|c|c|c|}
\hline $\begin{array}{c}\text { N } \\
\text { o }\end{array}$ & $\begin{array}{c}\text { Kode } \\
\text { Diagnosa }\end{array}$ & Gejala Dialami & $\begin{array}{c}\text { Diag } \\
\text { nosa }\end{array}$ \\
\hline 1 & D099 & $\begin{array}{c}\text { Bagian Tubuh Terasa Nyeri, } \\
\text { Gatal dan Kulit Melepuh }\end{array}$ & $? ? ?$ \\
\hline
\end{tabular}

Proses selanjutnya yaitu mencari rule yang sesuai dengan gejala-gejala yang dihadapi :

Rule 1 :IF Nyeri = Yes AND Gatal = Yes, Kulit Melepuh $=$ Yes THEN Penyakit $=$ Bulos

Rule 2 :-

Berdasarkan hasil inferensi dengan Forward Chaining, bahwa anak tersebut menderita jenis penyakit Impetigo Bulos.

\section{Penerapan Euclidean Probability}

Dari proses penelusuran dengan Forward Chaining dengan menghasilkan jenis penyakit yaitu : Impetigo Bulos, selanjutnya melakukan penerapan metode Euclidean Probability yang nantinya bertujuan untuk menghasilkan nilai kemungkinan atau tingkat kepastian gejala terhadap penyakit Impetigo Bulos.

Berikut ini merupakan langkah-langkah penyelesaian dari penerapan metode Euclidean Probability:

1) Menentukan Bobot Kondisi :

\begin{tabular}{|c|c|c|}
\hline No & Kondisi & Nilai \\
\hline 1 & Ya & 1 \\
\hline 2 & Tidak & 0 \\
\hline
\end{tabular}

\section{2)Menghitung Nilai Euclidean Probability} Penyakit

$I_{-}$Bulos $=\sqrt{\begin{array}{l}(1 * 0.6)^{2}+(1 * 0.2)^{2}+(1 * 0.6)^{2}+(0 * 0.4)^{2}+ \\ (0 * 0.2)^{2}+(0 * 0.2)^{2}+(0 * 0.2)^{2}\end{array}}=0.87$

$\mathrm{Im}_{-}$Krutosa $=\sqrt{(0 * 0.6)^{2}+(0 * 0.2)^{2}}=0$ 
3) Kesimpulan Perhitungan

Nilai Max $($ Bulos dan Krutosa $)=(0.87 ; 0)=0.87$

Berdasarkan hasil perhitungan metode Euclidean Probability maka diperoleh hasil kesimpulan pendiagnosaan dari gejala-gejala yang dialami pada kasus di atas, bahwa anak tersebut kemungkinan

Page|14 mengalami jenis penyakit Impetigo Buos dengan tingkat kepastian terhadap penyakit adalah 0.87 atau $87 \%$.

\section{E. Implementasi Sistem}

Penerapan Sistem Pakar ini adalah dengan membangun sebuah layanan konsultasi yang nantinya dapat dipergunakan dalam mengelola data-data atau pengetahuan yang berkaitan erat dengan penyakit Impetigo yang meliputi data gejal, data penyakit dan data probabilitas atau nilai kepastian serta pengelolaan data-data pasien yang melakukan Berikut adalah interface dari aplikasi yang telah disiapkan untuk melakukan pendeteksian terhadap penyakit Impetigo dengan menerapkan metode Euclidean Probability.

\section{1) Halaman Utama}

Halaman awal merupakan halaman yang hanya dapat diakses oleh pakar atau administrator yang telah memiliki wewenang dan hak akses yang digunakan untuk memasukkan mengelola data pasien, data penyakit, laporan dan info-info mengenai penyakit Impetigo, berikut ini merupakan tampilan halaman utama.

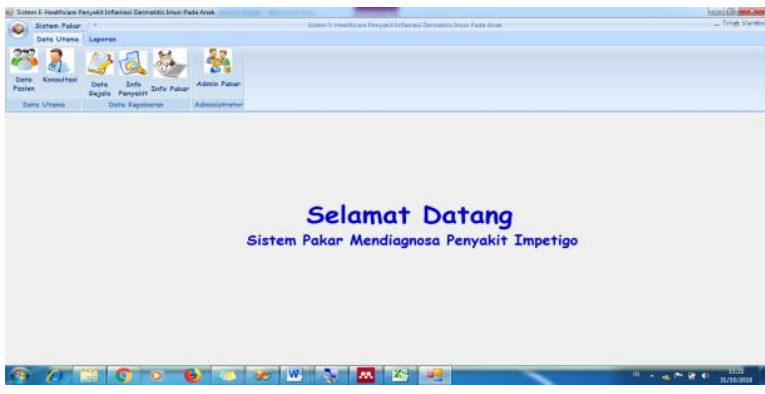

Gbr 1. Halaman Utama

Halaman ini akan tampil dan dapat dipergunakan, dengan terlebih dahulu admin atau pakar memasukkan username serta password pada form Login, dikarenakan sistem ini bersifat single user maka hanya admin atau pakar yang dapat menggunakan sistem ini. Berikut tampilan halaman Login:

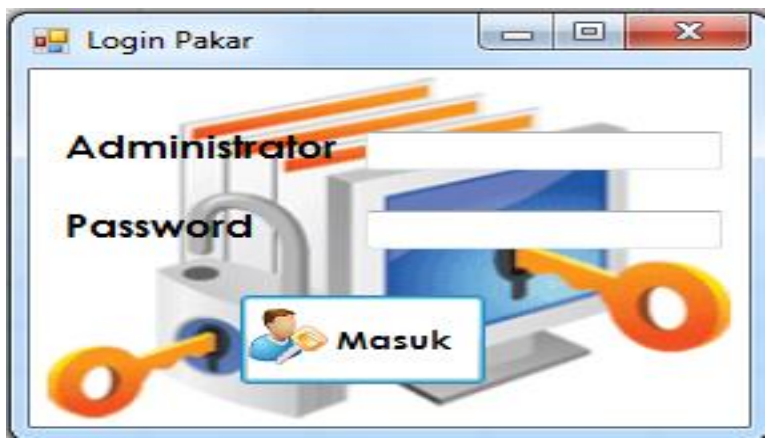

Gbr 2. Form Login
Tampilan Form Login ini akan tampil pertama kali disaat sistem layanan konsultasi ini diaktifkan, tampilan ini hanya dapat digunakan oleh pakar atau admin yang berwenang dalam mengelola data-data yang berkaitan dengan Penyakit Impetigo.

\section{2) Halaman Data Pasien}

Halaman data pasien digunakan untuk mengelolah data-data pasien yang akan melakukan konsultasi, halaman ini berisi data-data yang berkaitan dengan pasien yang meliputi: nama pasien, jenis kelamin, tanggal lahir, dan alamat. Setelah melakukan tahapan pengisian data pasien maka proses selanjutnya adalah melakukan pendaftaran untuk dapat memilih gejalagejala yang diderita oleh pasien.

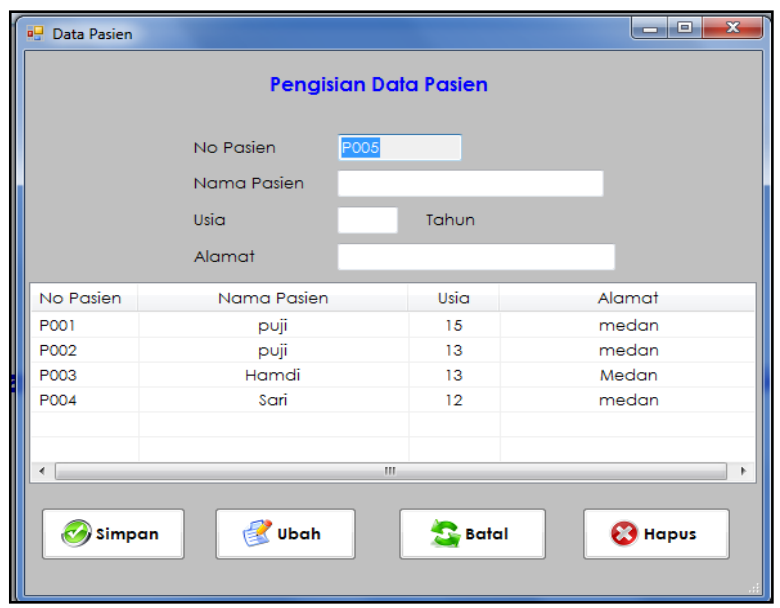

Gbr 3. Halaman Data Pasien

Proses pendiagnosaan akan dapat dilakukan dengan terlebih dahulu memasukkan identitas pasien terlebih dahulu pada menu data pasien.

\section{3) Halaman Diagnosa}

Halaman data diagnosa digunakan untuk mengelolah data diagnosa atau layanan konsultasi, berisi data tentang data pasien serta gejala-gejala yang terjadi pada pasien dan hasil dari diagnosa yang telah dilakukan. Layanan diagnosa ini akan menghasilkan penyakit yang diderita beserta nilai Euclidean Probability

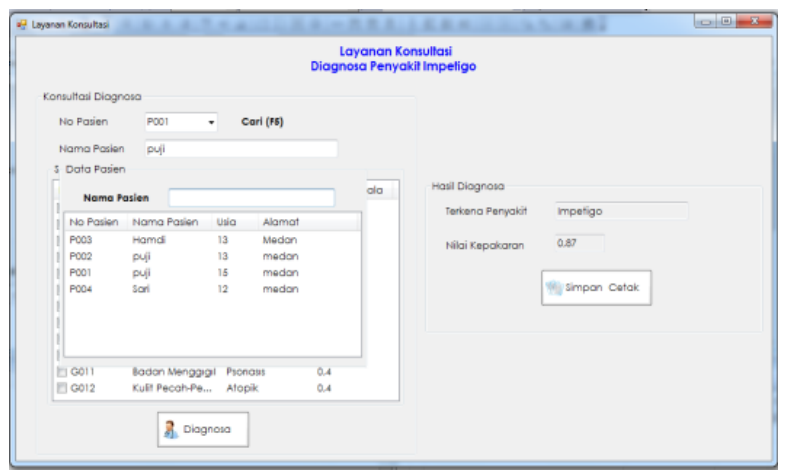

Gbr 4. Halaman Hasil Diagnosa 
Halaman data diagnosa berisi tentang beberapa data yang berkaitan tentang layanan konsultasi, diantaranya adalah nomor pasien, nama pasien, daftar gejala yang dialami dan jenis penyakit yang kemungkinan diderita beserta nilai probabilitas penyakit tersebut yang diperoleh dari perhitungan metode Euclidean Probability.

Pasien yang telah terdaftar dapat melakukan konsultasi dengan mencentang gejala-gejala yang dialami, kemudian setelah itu dengan menekan tombol diagnosa, akan menampilkan hasil diagnosa penyakit dan nilai kepastian yang diperoleh.

\section{4) Halaman Data Gejala}

Halaman data gejala dirancang untuk dapat digunakan dalam pengelolaan data-data gejala seperti bagian tubuh terasa nyeri, gatal, kulit melepuh, bercak merah, kulit berkerak kuning, demam, dan pembengkakan kelenjar serta daftar jenis penyakit Impetigo diantaranya Bulos dan Krutosa, yang nantinya akan dibentuk dalam basis pengetahuan penyakit berdasarkan gejala-gejala yang ada beserta nilai kepastian atau bobot probabilitas gejala. Disamping itu juga halaman ini berfungsi untuk membentuk aturan atau fakta terbaru mengenai penyakit Impetigo. Berikut tampilan halaman data gejala dari sistem ini :

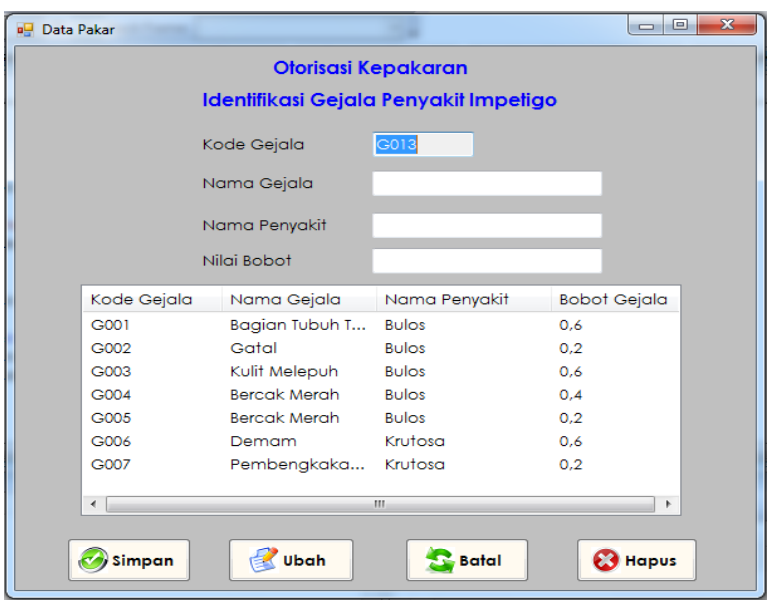

Gbr 5. Halaman Data Gejala

Halaman data gejala ini terdiri dari kode gejala, nama penyakit, nilai bobot, nama gejala dan pengolahan data seperti perubahan data, penambahan data serta penghapusan basis aturan yang ada, sehingga nantinya dapat terbentuk aturan baru dan kondisi baru, sehingga kedepannya sistem yang akan dikembangkan ini dapat dipergunakan berkelanjutan sesuai dengan pengembangan keilmuan tentang penyakit Impetigo pada anak.

\section{IV.KESIMPULAN}

Berdasarkan hasil penelitian yang telah dilakukan mengenai penerapan Euclidean Probability yang digunakan untuk pendeteksian penyakit Impetigo dengan mengakuisinya kedaalam sebuah sistem cerdas berbasis teknologi komputer yang telah dipaparkan, maka didapat beberapa kesimpulan, berikut adalah kesimpulan dari penelitian yang telah dilakukan :

1. Dalam pembangunan sistem layanan konsultasi ini terdapat langkah-langkah yang harus dilakukan, meliputi : pengumpulan data-data kepakaran yang meliputi data gejala, data penyakit, data kepastian atau probabilitas yang nantinya akan dibentuk dalam beberapa aturan-aturan dengan cara memindahkan keilmuan dan pengetahuan yang berkaitan dengan penyakit Impetigo ke dalam rulerule yang nantinya dapat diterapkan ke dalam sistem cerdas berbasis komputer.

2. Penerapan Euclidean Probability dalam mendiagnosa penyakit Impetigo ke dalam sebuah sistem layanan diagnosa dengan konsep keilmuan Sistem Pakar didahului dengan proses pengumpulan pengetahua tentang identifikasi gejala-gejala yang ada pada penyakit Impetigo yang nantinya dapat dibentuk ke dalam kumpulan rule-rule atau basis aturan, selanjutnya melakukan penelusuran dengan Forward Chaining terhadap basis aturan yang ada, kemudian melakukan tahapan perhitungan Euclidean Probability yang bertujuan untuk mendapatkan nilai probabilitas dan kepastian penyakit Impetigo berdasarkan pengidentifikasian dan penelusuran gejala-gejala yang dialami oleh pasien anak.

3. Sistem layanan konsultasi ini dirancang dengan menerapkan konsep Euclidean Probability dalam proses pendeteksian penyakit Impetigo yang pada umunya menyerang anak-anak telah sesuai berdasarkan tahapan-tahapan dan penerapan algoritma metode Euclidean Probability, sehingga sistem ini nantinya dapat diterapkan dan digunakan sebagai sistem pendiagnosaan penyakit Impetigo dan berfungsi sebagai pengambilan kesimpulan diagnosa awal.

\section{REFERENSI}

[1] A. Al-Ajlan, "The Comparison between Forward and Backward Chaining," Int. J. Mach. Learn. Comput., vol. 5, no. 2, pp. 106-113, 2015.

[2] S. Pakar, U. Mendiagnosis, and H. Pada, "Jambu Biji Menggunakan Metode Bayes," vol. 2, no. 1, pp. 78-81, 2017.

[3] Yeni Lestari Nasution, M. Mesran, S. Suginam, and F. Fadlina, "Sistem Pakar Untuk Mendiagnosis Penyakit Tumor Otak Menggunakan Metode Certainty Factor (CF)," $J$. INFOTEK, vol. 2, no. 1, pp. 0-4, 2017.

[4] Mohamad Hadi, M. Misdram, and R. F. A, "Perancangan Sistem Pakar Diagnosa Penyakit Ayam Dengan Metode Forward Chaining," JImp, vol. 2, no. no bagian volume, pp. 111-139, 2016.

[5] D. Gede and H. Divayana, "Application of Pineapple Diseases Expert System with FC-FL Method at Badung Regency Agriculture Department," vol. 4, no. 8, pp. 293-298, 2014.

[6] Minarn, I. Warman, and W. Handayani, "Case-Based Reasoning (Cbr) Pada Sistem Pakar Identifikasi Hama Dan Penyakit Tanaman Singkong Dalam Usaha Meningkatkan Produktivitas Tanaman Pangan," J. TEKNOIF, vol. 5, no. 1, pp. 41-47, 2017.

[7] B. F. Yanto, I. Werdiningsih, and E. Purwanti, "Aplikasi Sistem Pakar Diagnosa Penyakit Pada Anak Bawah Lima Tahun Menggunakan Metode Forward Chaining," J. Inf. Syst. Eng. Bus. Intell., vol. 3, no. 1, pp. 61-67, 2017.

[8] S. Qwaider and S. S. A. Naser, "Expert System for 
Page | 16 [11] J. Divya and K. Sreekumar, "A Survey on Expert System in Agriculture," Int. J. Comput. Sci. Inf. Technol., vol. 5, no. 6, pp. 7861-7864, 2014.

[12] M. S. Hossain, F. Ahmed, Fatema-Tuj-Johora, and K Andersson, "A Belief Rule Based Expert System to Assess Tuberculosis under Uncertainty," J. Med. Syst., vol. 41, no. 3, 2017.

[13] P. S. Ramadhan, U. Fatimah, and S. Pane, "Analisis Perbandingan Metode ( Certainty Factor, Dempster Shafer dan Teorema Bayes ) untuk Mendiagnosa Penyakit Inflamasi Dermatitis Imun pada Anak," Saintikom, vol. 17, no. 2, pp. $151-157,2018$.

[14] F. M. Hadini, "Detection System Milkfish Formalin AndroidBased Method Based on Image Eye Using Naive Bayes Classifier," vol. 9, no. 1, pp. 2-5, 2017.

[15] M. El Agha, A. Jarghon, and S. S. A. Naser, "Polymyalgia Rheumatic Expert System," no. August, 2017.

[16] A. Maseleno and M. Hasan, "The Dempster-Shafer Theory Algorithm and its Application to Insect Diseases Detection," vol. 50, pp. 111-120, 2013.

[17] H. R. Pourghasemi, B. Pradhan, C. Gokceoglu, M. Mohammadi, and H. R. Moradi, "Application of weights-ofevidence and certainty factor models and their comparison in landslide susceptibility mapping at Haraz watershed, Iran," Arab. J. Geosci., vol. 6, no. 7, pp. 2351-2365, 2013.

[18] A. Jamal and Sukadi, "Rancang Bangun Sistem Pakar Diagnosa Kerusakan Notebook Pada Widodo Computer Ngadirojo kabupaten Pacitan," J. Speed - Sentra Penelit. Eng. dan Edukasi -, vol. 7, no. 3, pp. 52-58, 2015.

[19] T. Wang, G. Zhang, J. Zhao, Z. He, Z. Wang, and M. J. Jiménez-Pérez, "Fault Diagnosis of Electric Power Systems Based on Fuzzy Reasoning Spiking Neural P Systems," IEEE Trans. Power Syst., vol. 30, no. 3, pp. 1182-1194, 2015.

[20] F. Masya, H. Prastiawan, and S. Mubaroq, "Application Design to Diagnosis of Bone Fracture ( Traditional ) using Forward Chaining Methods," Int. Res. J. Comput. Sci., vol. 3, no. 09 , pp. 23-30, 2016

[21] P. S. Ramadhan, "SISTEM PAKAR PENDIAGNOSAAN DERMATITIS IMUN MENGGUNAKAN TEOREMA BAYES," InfoTekJar(Jurnanl Nas. Inform. dan Teknol. Jaringan), vol. 3, no. 73, pp. 43-48, 2018.

[22] A. Maharani, Penyakit Kulit, 1st ed. Yogyakarta: Pustaka Baru Press, 2015.

\section{NOMENKLATUR}

Berdasarkan Berikut Nomenklatur persamaan atau rumus yang terdapat pada penalitian ini :

E arti dari Nilai Kondisi yang ada

NBE arti dari Nilai Bobot Evidence

n arti dari Banyaknya Objek 